\title{
THE CORRELATION OF THE LECTURERS' TEACHING METHODS AND COMPETENCIES TO THE STUDENTS' LEARNING ACHIEVEMENT
}

\author{
Mindani $^{1}$, Zulvia Trinova ${ }^{2}$, Afni Lindra ${ }^{3}$, Alimir ${ }^{4}$ \\ ${ }^{1}$ IAIN Bengkulu, ${ }^{2}$ UIN Imam Bonjol Padang, ${ }^{3,4}$ IAIN Bukittinggi \\ ${ }^{1}$ Jl. Raden Patah, Kec. Selebar, Kota Bengkulu, ${ }^{2}$ Anduring, Kec. Kuranji, Kota Padang, \\ 3,4Jl. Paninjauan, Kec. Mandiangin, Kota Bukittinggi \\ Email: mindani70@gmail.com ${ }^{1}$, zulviatrinova@uinib.ac.id², afnilidra@gmail.com³ \\ alimir@gmail.com ${ }^{4}$
}

\begin{abstract}
:
The lecturers' teaching methods and competencies vary at IAIN Bukittinggi so that it is important to know the correlation of the lecturers' teaching methods and competencies to the students' learning achievement at IAIN Bukittinggi. The method used of this research was quantitative method with ex post facto design. This research involved all lecturers and students of IAIN Bukittinggi as population and the sample was consisted of 40 people. The instrument used to collect the data was closedquestionnaire. The data were processed by scoring and inferential analyzing. The finding indicated that most of the lecturers at IAIN Bukittinggi applied lecture, question-answer, discussion, assignment, and problem solving methods. It was also found that the correlation of the lecturers' teaching methods and competencies to the students' achievement was only $2.8 \%$. Therefore, there was low correlation of the lecturers' teaching methods and competencies to the students' achievement in IAIN Bukittinggi.
\end{abstract}

\begin{abstract}
Abstrak:
Metode dan kompetensi mengajar dosen bervariasi di IAIN Bukittinggi sehingga penting untuk mengetahui hubungan antara metode pengajaran dan kompetensi dosen dengan prestasi belajar mahasiswa di IAIN Bukittinggi. Metode yang digunakan dalam penelitian ini adalah metode kuantitatif dengan desain ex post facto. Penelitian ini melibatkan semua dosen dan mahasiswa IAIN Bukittinggi sebagai populasi dan sampel terdiri dari 40 orang. Instrumen yang digunakan untuk mengumpulkan data adalah kuesioner tertutup. Data diproses dengan penilaian dan analisis inferensial. Temuan menunjukkan bahwa sebagian besar dosen di IAIN Bukittinggi menerapkan metode ceramah, tanya jawab, diskusi, penugasan, dan pemecahan masalah. Ditemukan juga bahwa korelasi antara metode pengajaran dan kompetensi dosen dengan prestasi belajar siswa hanya 2,8\%. Oleh karena itu, ada korelasi yang rendah antara metode pengajaran dan kompetensi dosen dengan prestasi siswa di IAIN Bukittinggi.
\end{abstract}

Keywords:

Method, Lecturers' Teaching Competencies, Learning Achievement

How to Cite: Mindani, Trinova, Z., Linda, A., \& Alimir. (2020). The Correlation of The Lecturers' Teaching Methods and Competencies to The Students' Learning Achievement. Lentera Pendidikan : Jurnal Ilmu Tarbiyah dan Keguruan, 23(1), 53-68. https://doi.org/10.24252/lp.2020v23n1i6. 


\section{INTRODUCTION}

Teaching is a very complex activity, so it is difficult to determine how to teach well. Teaching is a relationship among the people, because it needs good treatment of students, need to master the material to be taught, and need to adjust the teaching method with the lesson (Winataputra, Delfi, Pannen, \& Mustafa, 2014; Wahidin, 2017; Padmowihardjo, 2014; Handayani, 2011).

The teaching methods are very diverse. Each method has advantages and disadvantages. None of the methods is considered effective in every condition (Anas, 2014; \& Amin, 2015). Each method is seen as effective in one situation and may not be effective in another. Teaching is very good if it is done using various methods. A method is carried out based on relevant considerations and learning situations. To apply the method, the method must also be known, both its effectiveness and implementation (Nurdin, 2016; Yulianti, Iwan, \& Millah, 2018; \& Hanum, 2013).

There are several methods of teaching. Teachers and lecturers apply one of them or integrate one another in teaching and learning process in the class. The implementation of the method should be appropriate with the lesson because unsuitable method may make the students difficult to understand. Therefore, it is important to choose the suitable method. Several methods are presented as follow:

The first is Lecture Method. It can be seen as a delivery of the lesson through narrative (Amaliah, Fadhil, \& Nurulita, 2014). Many teachers and lecturers also use this method in teaching because its implementation is very simple and does not require complicated procedures. Cranton suggests that the lecture method is identical to what is known as the instructor centered method (Cranton, 2002). This happens because the instructor or lecturer is the only person responsible for delivering the knowledge to the students so that the direction of communication tends to be only one direction, from lecturer to students.

The second is Discussion Method. It is used by lecturers in class teaching (Sugiyanto, 2009; Astuti, Martini, \& Yamtinah, 2013). It is not effective for presenting new information. Discussion method is suitable for lecturers who want to help the students learning, thinking, and arguing the subject matter, help the students to evaluate using logic, give an opportunity to the students to formulate a topic and idea of thinking, help the students to find problems from information obtained, discuss and use learning materials from other groups, obtain information and know previous theories, motivate and develop broader learning, get stimulus and feedback about achieving learning goal (Nurrohmi, Utaya, \& Utomo, 2017; Wiranty \& Mastuti, 2018; \& Suparya, 2016).

The third method is called Question-Answer Method. It is a way of presenting courses in the form of questions that must be answered by the students. Question and answer method is the oldest method and is widely used in educational process, whether in family, in community, in schools/madrasah, or in universities (Siregar, 2014; Alfiyana, Risal, \& Amelia, 2019).

The fourth is Simulation Method. It can be interpreted as a way of teaching by doing artificial behavior (Ikhwan, 2017; \& Handayani, 2018). Simulation is basically a kind of game in teaching that is lifted from the reality of life. 
The fifth is named Project Method. It is a way of presenting material that starts from a problem (Qomariyah, 2019; \& Piona, 2017). This method can broaden students' thinking in facing life problems then it can foster students with the habit of applying knowledge, attitudes and skills in daily life in an integrated manner.

The next method is called Experimentation. It is a way of presenting lessons, where the students conduct experiments by experiencing and proving for themselves what they have learned (Andiasari, 2015; \& Sartika, 2012). In the teaching and learning process using this method the students are given the opportunity to experience or do it themselves, follow a process, observe an object, analyze, prove and draw their own conclusions about an object, state or process of something. Thus, the students are required to experience it themselves, reach the truth, or try to explore the proposition or law and draw conclusions from the process they experienced.

The seventh method is Assignment (recitation). This method presents material where the lecturer assigns a specific task to the students in their learning activities (Lestari, Hobri, Kristiana, 2015; Amin \& Ahmad, 2015). Assignments can be done in the classroom, in the campus yard, in the laboratory, in the library, in the workshop, at home or in the students' dormitory or anywhere.

Next methods are Socio-drama Method and Role Playing. These method are dramatizing behavior that have to do with social problems (Sitompul, 2015; \& Endriani, 2016). Role playing aims to describe a past event then appoint several students to perform roles in accordance with the purpose of the story. The benefit is helping someone change their attitude so far. In addition, role playing is a planned learning activity designed to achieve specific educational goals.

The Ninth method is Demonstration. This method is a way of presenting lecture material by demonstrating the process to the students, certain situations that are being studied, both actual and imitation accompanied by verbal explanations (Gilboy, Heinerichs, Pazzaglia, 2015; \& Wati, 2020).

The tenth is Problem Solving Method. It is a method of thinking that starts with finding data until drawing conclusions. There are several steps in applying this method; firstly, there are obvious problems to solve. The problem comes from students according to their abilities. Secondly, the students look for data or information that can be used to solve the problems, such as reading books, researching, asking questions, discussing, etc. Thirdly, establishing a temporary problem-solving schedule for the problem (Ulfhanny, 2018; Mutia, Muhamad, \& Rahman, 2018).

The eleventh method is Exercising or Training Method. It is a good way of teaching to instill good habits. This method can be used to acquire dexterity, accuracy, opportunity, and skills (Nurhasanah, 2017).

The twelfth is Tourism Work Method. It is also called fieldwork which aims to review certain places, such as visiting historical sites, museums, and so on. Tourism can be done in a short time or a long time (Suridah, Fajar, Fahrurrozi, Angraeni, Ulfa, \& Sonia 2020).

The thirteenth is Inquiry-Discovery Method. The method is basically two methods that are interrelated to one another (Hamid, 2019). Inquiry means investigation, while 
discovery means discovery. By carrying out an investigation, students can obtain an invention. With inquiry and discovery methods, students do a high-value mental process, in addition to other physical activity processes.

The last method is Combined Method. Lecture is efficient way to present pedagogy, but that using lecture as the sole mode of instruction presents less potent than combined (traditional plus active learning) teaching method (Kolesnikova, 2016).

The important thing for the lecturer in using the teaching method is to consider the factors regarding the suitability of the method with the teaching objectives, available resources and facilities, the conditions and conditions of teaching and learning, student conditions and the time available.

Teaching ability relates to the skills possessed by lecturers in delivering lecture material. Lecturers as executors of educational assignments have a hand in choosing teaching tools, teaching aids and other teaching media. Hamalik (2004) and Fajarwati (2016) suggested that the use of teaching media in teaching and learning process can improve new desires, interests, motivation and stimulation of learning activities, and even bring psychological influence on students.

Turney (1973) states that there are eight basic teaching skills that are considered very important in the success of teaching and learning activities namely the skills to ask questions, provide reinforcement, hold variations, explain, open and close lessons, guide small group discussions, manage classes, and teach small groups and individual.

The ability to manage learning can be seen in various aspects as stated by Djamas (2005) they are; firstly, the aspect of mastery of teaching materials with indicators must be able to understand the structure of knowledge and master the specific substance in accordance with the types of services needed by students. Secondly, the aspects of syllabus development/preparation of lecture program units with indicators are able to describe the learning objectives, choose and organize the material, determine learning methods and media, develop assessment tools, and determine or allocate the time. Thirdly, the aspects of implementing teaching and learning interactions with indicators are able to open lessons and teach material, able to use methods and use media, able to use communicative language and motivate students, able to organize activities and interactions with students communicatively, able to conclude learning and provide feedback. Fourthly, Learning achievement assessment aspects with indicators able to choose questions based on the level of difficulty and differentiation, able to correct valid questions, able to check answers and classify assessment results, able to process and analyze assessments, able to identify the level of variation in the results of the assessment, and conclude the results of the assessment clearly and logically.

Learning achievement has several functions including indicators of the quality and quantity of knowledge that has been mastered, as well as various information and educational motivations. This is an indicator of the absorption of students. The teaching methods that are used by lecturers vary and the lecturers' ability to teach in utilizing a variety of teaching skills also vary which will certainly have an effect on the students' achievements in the class. 


\section{RESEARCH METHOD}

The method used of this research was quantitative method with ex post facto design. This research involved all lecturers and students of IAIN Bukittinggi as population. The sample taken was $5 \%$ of the population which was consisted of 40 people. This research was a correlational research that was intended to find out the correlation between variables. By using correlational techniques, researchers knew the correlation of the lecturers' methods and competencies to the students' achievement. The instrument used to collect the data was closed-questionnaire. It was arranged based on indicators that could answer the problem. These indicators were compiled from each variable by seriously considering the use of content and construct validities. This study also used documentation review to gain additional data.

The data were processed by scoring and inferential analyzing. Some hypotheses are tested using the correlation technique (Anova). To find out the correlation of the independent variables to the dependent variable, regression analysis was used with the formula: $\mathrm{Y}=\mathrm{B} 0+\mathrm{B} 1 \mathrm{X} 1+\mathrm{B} 2 \mathrm{X} 2+\sum$. All data were done through computer media, namely the use of a statistical analysis system (SAS) program.

\section{RESULT AND DISCUSSION}

Based on the results of the study, can be described lecturers' teaching methods:

\section{The Lecturers' Teaching Method}

\section{Lecture Method}

Most of the lecturers in IAIN Bukittinggi applied lecture method. This method showed that the lecturers were very beneficial for the students. They are the center of the information and knowledge. The lecturers explain the lesson and the students have to listen carefully to get deep understanding. The following table is the data found about the application of lecture method at IAIN Bukittinggi:

Table 1. The Use of Lecture Method

\begin{tabular}{|c|c|c|c|c|c|c|c|c|c|c|c|}
\hline \multirow[b]{2}{*}{ No. } & \multirow{2}{*}{$\begin{array}{l}\text { Teaching } \\
\text { Method }\end{array}$} & \multicolumn{10}{|c|}{ Alternative Answers } \\
\hline & & Always & $\%$ & Often & $\%$ & $\begin{array}{l}\text { Some- } \\
\text { times }\end{array}$ & $\%$ & $\begin{array}{c}\text { Almost } \\
\text { Never }\end{array}$ & $\%$ & Never & $\%$ \\
\hline 1. & $\begin{array}{l}\text { Lecture } \\
\text { Method }\end{array}$ & 23 & 57.5 & 11 & 27.5 & 6 & 15 & 0 & 0 & 0 & 0 \\
\hline
\end{tabular}

Based on the respondents' answers to the questionnaire that had been provided, the data found were 23 people or $57.5 \%$ of the lecturers used the lecture method, 11 people or $27.5 \%$ stated often and $15 \%$ stated sometimes. The data indicated that more than half of the total number of the lecturers taught using lecture method at IAIN Bukittinggi.

\section{Discussion Method}

To activate the students' critical thinking, the lecturers of IAIN Bukittinggi use discussion method. It helps the students to learn, think, and argue the subject matter. 
Discussion method lets the students to share their thoughts and opinions with others. The finding about the lecturers using this method is described in the following table:

Table 2. The Use of Discussion Method

\begin{tabular}{|c|c|c|c|c|c|c|c|c|c|c|c|}
\hline \multirow[b]{2}{*}{ No. } & \multirow{2}{*}{$\begin{array}{l}\text { Teaching } \\
\text { Method }\end{array}$} & \multicolumn{10}{|c|}{ Alternative Answers } \\
\hline & & Always & $\%$ & Often & $\%$ & $\begin{array}{l}\text { Some- } \\
\text { times }\end{array}$ & $\%$ & $\begin{array}{l}\text { Almost } \\
\text { Never }\end{array}$ & $\%$ & Never & $\%$ \\
\hline 1. & $\begin{array}{c}\text { Discussion } \\
\text { Methods }\end{array}$ & 15 & 37.5 & 20 & 59 & 5 & $\begin{array}{c}12 . \\
5\end{array}$ & 0 & 0 & 0 & 0 \\
\hline
\end{tabular}

Lecturers who stated often applied discussion method were 20 people or 59\%, 15 people or $37.5 \%$ stated always and 5 people or $12.5 \%$ stated sometimes. Hence, the lecturers of IAIN Bukittinggi quite often used the method of discussion in lectures, which made the students more trained in expressing their opinions.

\section{Question-Answer Method}

The lecturers of IAIN Bukittinggi use question and answer method to know the students' understanding of a lesson. This method helps the lecturers to give more explanation when the students cannot answer the lecturers' questions or they can ask to the lecturers about the lesson that they do not understand yet. The following table describes about the implementation of question and answer method in IAIN Bukittinggi:

Table 3. The Use of Question and Answer Method

\begin{tabular}{|c|c|c|c|c|c|c|c|c|c|c|c|}
\hline \multirow[b]{2}{*}{ No. } & \multirow{2}{*}{$\begin{array}{l}\text { Teaching } \\
\text { Method }\end{array}$} & \multicolumn{10}{|c|}{ Alternative Answers } \\
\hline & & $\begin{array}{c}\text { Alway } \\
\text { s }\end{array}$ & $\%$ & Often & $\%$ & $\begin{array}{l}\text { Some- } \\
\text { times }\end{array}$ & $\%$ & $\begin{array}{c}\text { Almost } \\
\text { Never }\end{array}$ & $\%$ & Never & $\%$ \\
\hline 1. & $\begin{array}{l}\text { Question } \\
\text { and } \\
\text { Answer } \\
\text { Methods }\end{array}$ & 21 & $\begin{array}{c}52 . \\
5\end{array}$ & 14 & $\begin{array}{l}3 \\
5\end{array}$ & 4 & 10 & 0 & 0 & 0 & 0 \\
\hline
\end{tabular}

There were 21 people or $52.5 \%$ of the lecturers used the question and answer method, 14 people or $35 \%$ stated often and 4 people or $10 \%$ stated sometimes. The lecturers also used the question and answer method more than any other method.

\section{Simulation Method}

Simulation method provides meaningful practice situations for the students, it can develop their abilities. The lecturers of IAIN Bukittinggi use this method to engage the students' deep learning to empower their understanding. The following table shows the use of Simulation Method in IAIN Bukittinggi: 
Table 4. The Use of Simulation Methods

\begin{tabular}{lccccccccccccc}
\hline & \multirow{10}{*}{ Neaching } & \multicolumn{10}{c}{ Alternative Answers } \\
\cline { 3 - 12 } & Method & Always & $\%$ & Often & $\%$ & $\begin{array}{c}\text { Some- } \\
\text { times }\end{array}$ & $\%$ & $\begin{array}{c}\text { Almost } \\
\text { Never }\end{array}$ & \% & Never & $\%$ \\
\hline 1. & $\begin{array}{c}\text { Simulation } \\
\text { Methods }\end{array}$ & 0 & 0 & 7 & 17.5 & 17 & 42.5 & 4 & 1 & 12 & 30 \\
\hline
\end{tabular}

Based on the data obtained, the highest frequency was alternative answer sometimes which reached 17 people or $42.5 \%$. There were 7 people or $17.5 \%$ stated often, almost never 4 people or $10 \%$, and 12 people or $30 \%$ stated never.

\section{Project Method}

Project method allows the students to explore and to experience the environment through their senses. This method involves the students to study, to do research, to use their experiences, skills, interests, and capabilities in a sequence of activities as a task from the lecturers. The table 5 describes the implantation of Project Method at IAIN Bukittinggi.

Table 5. The Use of Project Method

\begin{tabular}{llcccccccccc}
\hline No. & $\begin{array}{c}\text { Teaching } \\
\text { Method }\end{array}$ & Always & $\%$ & Often & $\begin{array}{c}\text { Alternative Answers } \\
\text { Some- } \\
\text { times }\end{array}$ & $\begin{array}{c}\text { Almost } \\
\text { Never }\end{array}$ & \% & Never & \% \\
\hline 1. & $\begin{array}{l}\text { Project } \\
\text { Method }\end{array}$ & 0 & 0 & 2 & 5 & 5 & 12.5 & 10 & 25 & 23 & 57.5 \\
\hline
\end{tabular}

There were 23 people or $57.5 \%$ who said never, around 10 people or $25 \%$ stated almost never, there were 5 people or $12.5 \%$ stated sometimes, and 2 people or $5 \%$ stated often. Lecturers generally never do the project method because this method was considered ineffective and required a lot of preparation to complete a lecture material project.

\section{Experimental Method}

Experimental method gives opportunity to the students whether individual or group to get information and explanation to process or experiment. The lecturers guide them to process of experiment in order to make the students understand about it. By applying this method, the students have the opportunity to do their experiment by themselves, follow the process of this method, and show the object. The implementation of experimental method at IAIN Bukittinggi is presented in the following table:

Table 6. The Use of Experimental Method

\begin{tabular}{|c|c|c|c|c|c|c|c|c|c|c|c|}
\hline \multirow[b]{2}{*}{ No } & \multirow{2}{*}{$\begin{array}{l}\text { Teaching } \\
\text { Method }\end{array}$} & \multicolumn{10}{|c|}{ Alternative Answers } \\
\hline & & Always & $5 \%$ & Often & $\%$ & $\begin{array}{l}\text { Some- } \\
\text { times }\end{array}$ & $\%$ & $\begin{array}{c}\text { Almost } \\
\text { Never }\end{array}$ & $\%$ & Never & $\%$ \\
\hline 1. & $\begin{array}{c}\text { Experimenta } \\
\text { Methods }\end{array}$ & 1 & 2.5 & 6 & 15 & 9 & 22.5 & 5 & 12.5 & 19 & 47.5 \\
\hline
\end{tabular}


Based on the table 6, there were 19 people or $47.5 \%$ stated never, around 9 people or $22.5 \%$ stated sometimes, there 6 people or $15 \%$ said often, there 5 people or $12.5 \%$ stated almost never, and 1 person or $2.5 \%$ stated always. Thus, most of the lecturers did not use this experimental method in teaching and learning process.

\section{Assignment/Task (Recitation) Method}

An assignment is one of the teaching methods that aims to help the students independently get academic competencies, whether it is in individual or group. The assignment may various, depends what lesson that the lecturers taught to them and types of assignment appropriate to it. The use of this method at IAIN Bukittinggi is described in the following table:

Table 7. The Use of Task or Recitation Method

\begin{tabular}{lcccccccccccc}
\hline & Teaching & \multicolumn{10}{c}{ Alternative Answers } \\
\cline { 3 - 10 } No. & Method & Always & \% & Often & $\begin{array}{c}\text { Some- } \\
\text { times }\end{array}$ & \% & $\begin{array}{c}\text { Almost } \\
\text { Never }\end{array}$ & \% & Never & \% \\
\hline 1. & $\begin{array}{c}\text { Task and } \\
\text { Recitation } \\
\text { Methods }\end{array}$ & 16 & 40 & 16 & 40 & 7 & 17.5 & 0 & 0 & 1 & 2.5 \\
\hline
\end{tabular}

There were 16 people or $40 \%$ stated each always and often using assignment this method in teaching at IAIN Bukittinggi. Around 7 people or $17.5 \%$ and 1 person or $2.5 \%$ said sometimes and never, respectively. Hence, the implementation of assignment method or recitation was quite high at IAIN Bukittinggi.

\section{Socio-drama Method and Role Playing}

Socio-drama and role playing are teaching methods in which the lecturers provide opportunity to the students performing certain role playing activities in the life of social community. It can stimulate the students' attitudes, knowledge, and skills. These methods help the students' in learning activities. The use of these methods at IAIN Bukittinggi is described of the table 8.

Table 8. The Use of the Socio-drama Method and Role Playing

\begin{tabular}{cccccccccccccc}
\hline & Teaching & \multicolumn{10}{c}{ Alternative Answers } \\
\cline { 3 - 11 } No. & Method & Always & \% & Often & $\begin{array}{c}\text { Some- } \\
\text { times }\end{array}$ & $\begin{array}{c}\text { Almost } \\
\text { Never }\end{array}$ & \% & Never & \% \\
\hline $\begin{array}{l}\text { Sociodrama } \\
\text { Method and } \\
\text { Role Playing }\end{array}$ & 0 & 0 & 6 & 15 & 16 & 40 & 5 & 12.5 & 13 & 32.5 \\
\hline
\end{tabular}

Based on data that had been collected, the highest frequency was sometimes which reached 16 people or $40 \%$ stated it. There were 6 people or $15 \%$ stated often, and 5 people or $12.5 \%$ stated almost never. There were 13 people or $32.5 \%$ said never applying Sociodrama method and role playing. 


\section{Demonstration Method}

Demonstration teaching method sets up to potential concept effectively in learning material. It occurs in teaching and learning process when the students find difficult to connect theories and the actual practice or when they cannot understand the application of theories. The following table presents the use of this method at IAIN Bukittinggi.

Table 9. The Use of Demonstration Method

\begin{tabular}{cccccccccccc}
\hline & Teaching & \multicolumn{1}{c}{ Alternative Answers } \\
\cline { 2 - 10 } No. & Method & Always & $\%$ & often & \% & $\begin{array}{c}\text { Some- } \\
\text { times }\end{array}$ & \% & $\begin{array}{c}\text { Almost } \\
\text { Never }\end{array}$ & \% & Never & \% \\
\hline 1. $\begin{array}{c}\text { Demonstration } \\
\text { Method }\end{array}$ & 6 & 15 & 6 & 15 & 19 & 47.5 & 2 & 5 & 7 & 17.5 \\
\hline
\end{tabular}

Based on the finding, it showed that sometimes as the alternative answers reached $47.5 \%$. There were 6 people or $15 \%$ stated both of always and often alternative answers. There were 2 people or $5 \%$ stated almost never and 7 people or $17.5 \%$ stated never. Most of the lecturers at IAIN Bukittinggi sometimes used this demonstration method, because it took a lot of ability to demonstrate something related to the material taught by them in class.

\section{Problem Solving Method}

The students learn by working on problems in problem solving method. It enables the students to get new knowledge by facing problems. They are expected to analyze, understand, observe, and find solution about the problem faced. The following table shows the application of this method at IAIN Bukittinggi.

Table 10. The Use of the Problem Solving Method

\begin{tabular}{ccccccccccccc}
\hline & Neaching & \multicolumn{10}{c}{ Alternative Answers } \\
\cline { 2 - 10 } & Method & Always & \% & Often & $\begin{array}{c}\text { Some- } \\
\text { times }\end{array}$ & $\%$ & $\begin{array}{c}\text { Almost } \\
\text { Never }\end{array}$ & Never & \% \\
\hline 1. & $\begin{array}{c}\text { Problem } \\
\text { Solving } \\
\text { Method }\end{array}$ & 3 & 7.5 & 16 & 40 & 13 & 32.5 & 2 & 5 & 6 & 15 \\
\hline
\end{tabular}

There was $40 \%$ of the respondents stated often which mean that this method was frequently used by the lecturers. There were 3 people or $7.5 \%$ stated always and 13 people or $32.5 \%$ who said sometimes. Only 2 people or $5 \%$ stated almost never, and 6 people or $15 \%$ stated never.

\section{Exercising or Training Method}

Exercising or training method stimulates the students' interest for physical exercise. This method is introduced to physical education. As the combination of training and teaching, it can achieve not only the goal of teaching activity but also the purpose of training. This strategy expands the students' relevant skills and tactical knowledge. The following table presents the lecturers data at IAIN Bukittinggi in applying this method. 
Table 11. The Use of Training Method

\begin{tabular}{cccccccccccc}
\hline & Teaching & \multicolumn{8}{c}{ Alternative Answers } \\
\cline { 2 - 10 } No. & Method & Always & \% & Often & $\begin{array}{c}\text { Some- } \\
\text { times }\end{array}$ & $\begin{array}{c}\text { Almost } \\
\text { Never }\end{array}$ & Never & \% \\
\hline 1. & $\begin{array}{c}\text { Exercising } \\
\text { or Training } \\
\text { Method }\end{array}$ & 26 & 65 & 10 & 25 & 3 & 7.5 & 0 & 0 & 1 & 2.55 \\
\hline
\end{tabular}

There were 26 respondents stated they always used that strategy. Only $2.25 \%$ said never. There were 10 and 3 people stated often and sometimes, respectively. None of them stated almost never apply training method at IAIN Bukittinggi.

\section{Fieldwork or Tourism Work Method}

Fieldwork method has benefits including holistic, where all the senses are engaged and the impacts are more than cognitive. This strategy can get students more experience and information. The data of the lecturers at IAIN Bukittinggi relating to the implementation of this method are presented in table 12 .

Table 12. The Use of Tourism Work Method

\begin{tabular}{cccccccccccccc}
\hline & Teaching & \multicolumn{10}{c}{ Alternative Answers } \\
\cline { 3 - 10 } & Method & Always & \% & Often & $\begin{array}{c}\text { \% } \\
\text { Nome- } \\
\text { times }\end{array}$ & $\begin{array}{c}\text { Almost } \\
\text { Never }\end{array}$ & \% & Never & \% \\
\hline 1. & $\begin{array}{c}\text { Tourism } \\
\text { Work } \\
\text { Method }\end{array}$ & 0 & 0 & 1 & 2.5 & 5 & 17.5 & 7 & 17.5 & 27 & 67.5 \\
\hline
\end{tabular}

The highest frequency was the option of never. It reached 27 people or $67.5 \%$ which meant most of the lecturers of IAIN Bukittinggi never did a fieldtrip for teaching. There were 7 people or $17.5 \%$ stated almost never. The respondents said sometimes were 5 people or $17.5 \%$, and only 1 person or $2.5 \%$ said often.

\section{Inquiry-Discovery Method}

Inquiry-discovery method takes place in problem solving situations where the students draw on their own experience and prior knowledge. It also a method of instruction through which the students interact with their environment by exploring and manipulating objects, wrestling with questions and performing experiments. The following data show the implementation of this method at IAIN Bukittinggi.

Table 13. The Use of Inquiry-Discovery Method

\begin{tabular}{|c|c|c|c|c|c|c|c|c|c|c|c|}
\hline \multirow[b]{2}{*}{ No. } & \multirow{2}{*}{$\begin{array}{l}\text { Teaching } \\
\text { Method }\end{array}$} & \multicolumn{10}{|c|}{ Alternative Answers } \\
\hline & & Always & $\%$ & Often & $\%$ & $\begin{array}{l}\text { Some- } \\
\text { times }\end{array}$ & $\%$ & $\begin{array}{c}\text { Almost } \\
\text { Never }\end{array}$ & $\%$ & Never & $\%$ \\
\hline 1. & $\begin{array}{l}\text { Inquiry and } \\
\text { Discovery } \\
\text { Methods }\end{array}$ & 15 & 37.5 & 20 & 59 & 5 & 12.5 & 0 & 0 & 0 & 0 \\
\hline
\end{tabular}


Most of the lecturers at IAIN Bukittinggi used inquiry-discovery method as presented in table 13. There were 59\% stated often. Around $37.5 \%$ said always and 5 peoples stated sometimes.

\section{Combined Method}

Several lecturers at IAIN Bukittinggi used combined method in teaching. Most of them combined lecture and question-answer methods. By the implementation of these methods, the students can improve their understanding and test their knowledge through answering the questions from the lecturers. The following table describes the implementation of the combined method at IAIN Bukittinggi.

Table 14. The Use of Combined Method

\begin{tabular}{lccccccccccc}
\hline & Teaching & \multicolumn{10}{c}{ Alternative Answers } \\
\cline { 3 - 11 } No. & Method & Always & $\%$ & often & $\%$ & $\begin{array}{c}\text { Some- } \\
\text { times }\end{array}$ & $\begin{array}{c}\text { Almost } \\
\text { Never }\end{array}$ & \% & Never & $\%$ \\
\hline 1. & $\begin{array}{c}\text { Combined } \\
\text { Method }\end{array}$ & 13 & 32.5 & 11 & 27.5 & 16 & $\begin{array}{c}4 \\
0\end{array}$ & 0 & 0 & 0 & 0 \\
\hline
\end{tabular}

There were $32.5 \%$ of the respondents stated that they always used combined method in teaching at IAIN Bukittinggi. Several of the lecturers or around $40 \%$ sometimes applied it. None of them stated almost never and never.

\section{The Lecturers' Teaching Competencies}

The lecturers' competencies to manage students' learning are very important. Therefore, the key to successful learning is seen from the factors of learning management, the lecturers are required to do some learning management as follows: The first is mastery of teaching materials; the ability to understand teaching materials and the structure of knowledge related to the field of study that must be mastered by lecturers so that the students easily obtain the knowledge. The second is the ability to design a syllabus and develop it into specific topics of learning. Lecturers must be able to describe the learning objectives by selecting and determining the material and organizing learning. The next is implementation and interaction of teaching and learning; good learning implementation seen from a good process, such as presenting material, learning strategies, teaching tools or media, and motivating the students who are taking part in learning that finally brings up and provides good feedback. The last is evaluating the students' learning achievement; in terms of evaluating students' achievement, lecturers must be smart and have the ability to evaluate and select the exam questions and the difficulty level, engage to solve question problems, classify analyze the results of the assessment.

\section{The Students' Learning Achievement}

Students' learning achievement is the result achieved by the students in the learning process in the form of numbers or grades given by the lecturer after an evaluation is held. Grading score is an accumulation of the entire examination, discussion, individual and group assignments, and activities in the teaching and learning process. It can be numbers 
such as 4, 3, 2, and 1 with the symbols of the letters A, B, C, and D of each course. All courses that have been programmed and tested in each semester are calculated to get the students' Grade Point Average (GPA). From 40 samples of this research, their GPA varied each other. After counting through SPSS, the lowest score was 2.16 and the highest score was 3.66. The students' scores obtained were 2.99 of the average value (mean) and 0.35 of standard deviation (SD). The frequency of the students' learning achievement is presented in Table 15:

Table 15. The Students' Learning Achievement in IAIN Bukittinggi

\begin{tabular}{ccccc}
\hline No. & Score Interval & Category & Frequency & Percent \\
\hline 1. & $1-2.74$ & Low & 7 & 17.5 \\
2. & $2.75-3.49$ & Average & 31 & 77.5 \\
3. & $3.50-4.0$ & High & 2 & 5 \\
\hline & Total & & 40 & 100 \\
\hline
\end{tabular}

From table 15, it showed that the students' learning achievement of IAIN Bukittinggi was in average category with the highest frequency of 31 people or $77.5 \%$. Those students who got scores $2.75-3.49$ were classified as satisfactory or very satisfactory predicate, 7 people or $17.5 \%$ got low scores (1.0 - 2.74) was classified quite satisfactory, and 2 people or $5 \%$ got the highest scores (3.50-4.0) or classified cum laude.

\section{The Correlation of the Lecturers' Teaching Methods and Competencies to the Students' Learning Achievement}

To find out the correlation between the lecturers' teaching methods and the students' achievement, the data was analyzed using product moment correlation formula through SAS. It could be seen that the value of $r$-table for $5 \%$ error level with $n=40$ was obtained 0.0878 . In the other words, $r$-test was smaller than $r$-table $(0.0878<0.312)$. Hence, there was no correlation between the lecturers' learning methods and the students' learning achievement.

From the results of partial correlation analysis, it was found that $r$-table for $5 \%$ error level with $n=40$ obtained 0.312 while $r$-test got 0.146 . It indicated that the r-test was smaller than $r$-table $(0.146<0.312)$. Thus, there was no correlation of the lecturers' teaching ability or proficiency to the students' learning achievement.

The correlation of the lecturers' methods and competencies to the students' learning achievement was analyzed through analysis of variance. It was known that $r$-table for $5 \%$ of error level with $n=40$ obtained 0.312 while $r$-arithmetic got 0.541 . In the other words, $\mathrm{r}$-arithmetic was greater than $\mathrm{r}$-table $(0.541>0.312)$. Therefore, there was low correlation of the lecturers' teaching methods and competencies to the students' achievement in IAIN Bukittinggi.

The correlation was indicated with the determination coefficient $\mathrm{r} 2=0.028$. It meant that the correlation was only $2.8 \%$ while the rest was influenced by other factors. The main influence model was $\mathrm{Y} 2=\mathrm{B} 0+\mathrm{b} 1 \mathrm{X} 1+\mathrm{b} 2 \mathrm{X} 2+\mathrm{E}=3.53+0.00376 \mathrm{X} 1+0.004391 \mathrm{X} 2+4.467$. From this simple linear regression analysis, it showed that the lecturers' teaching methods and competencies were not the main factors influencing the students' achievement IAIN 
Bukittinggi. Other factors influenced were external factor such as environment, learning conditions, learning goals, and feedback by the lecturer and internal factors such as their personal motivation, attention, perception, and memory.

The lecturers of IAIN Bukittinggi often use lecture, question and answer, discussion, assignment (recitation), and problem solving methods. The correlation of the lecturers' teaching methods and competencies to the students' achievement at IAIN Bukittinggi was gained $2.8 \%$. It was very low compared to the other factors.

\section{CONCLUSION}

Based on the findings and discussion that had been presented previously, it could be concluded that most of the lecturers at IAIN Bukittinggi applied lecture, question-answer, discussion, assignment, and problem solving methods. The teaching skills and competencies of lecturers at IAIN Bukittinggi were considered quite high. It could be seen in the mastery of study material, syllabus development and preparation of semester learning plans, interactions, communication of teaching and learning, and assessment of students' learning achievement. In this research, it was also found that there was low correlation of the lecturers' teaching methods and competencies to the students' achievement in IAIN Bukittinggi.

After conducting this research, it is suggested that the lecturers of Bukittinggi IAIN Lecturers should use various methods in teaching and learning process, so they can follow the technology development of teaching and learning. It is expected that the leadership of IAIN Bukittinggi improves and conducts teaching training for the lecturers, especially for lecturers with non-educational backgrounds.

\section{REFERENCES}

Alfiyana, N., Risal, M. I., \& Amelia, R. (2019). Metode Tanya Jawab dan Penerapannya dalam Materi Sejarah Kebudayaa Islam. Murobbi: Jurnal Ilmu Pendidikan dan Kependidikan, 1(2). https://doi.org/https://doi.org/10.22219/jkpp.v3i1.2186.

Amaliah, R. R., Fadhil, A., \& Narulita, S. (2014). Penerapan Metode Ceramah dan Diskusi dalam Meningkatkan Hasil Belajar PAI di SMA Negeri 44 Jakarta. Studi Al-Qur'an; Membangun Tradisi Berfikir Qur'an, 10(2), 119-131. http://journal.unj.ac.id/unj/index.php/jsq/article/view/4441.

Amin, A. (2015). Metode dan Pembelajaran Agama Islam. Bengkulu: IAIN Bengkulu Press.

Amin, M. \& Ahmad. (2015). Upaya Meningkatkan Hasil Belajar Siswa Pada Materi Permintaan dan Penawaran Melalui Metode Pemberian Tugas (Resitasi) Di Kelas X SMA Negeri 1 Samalanga. Sains Ekonomi dan Edukasi, III(2). http://jfkip.umuslim.ac.id/index.php/jsee/article/view/267.

Anas, M. (2014). Mengenal Metodologi Pembelajaran. https://books.google.co.id/books?id=o7b5AwAAQBAJ\&printsec=frontcover\&hl=i $\mathrm{d} \&$ source=gbs_ge_summary_r\&cad $=0 \# \mathrm{v}=$ onepage $\& \mathrm{q} \& \mathrm{f}=$ false.

Andiasari, L. (2015). Penggunaan Model Inquiry dengan Metode Eksperimen dalam Pembelajaran IPA di SMPN 10 Probolinggo. Jurnal Kebijakan Dan Pengembangan 
Pendidikan,

$3(1)$,

$15-20$

http://ejournal.umm.ac.id/index.php/jkpp/article/view/2186.

Astuti, H., Martini, K., \& Yamtinah, S. (2013). Efektivitas Penggunaan Media TTS Dan Kartu Soal di Dalam Metode Diskusi pada Materi Koloid Kelas XI Semester Genap SMAN Colomadu Karanganyar Tahun Pelajaran 2011/2012. Jurnal Pendidikan Kimia Universitas Sebelas Maret, 2(1), 85-91.

Cranton, P. (2002). Teaching for transformation. New Directions for Adult and Continuing Education, 93, 63-72.

Djamas, N. (2005). Strategi Peningkatan Mutu Dosen PTAI Pendidikan Tinggi Agama Islam. Puslitbang Pendidikan Agama dan Keagamaan.

Endriani, A. (2016). Pengaruh Teknik SosiodarmaTerhadap Kepercayaan Diri Siswa MA Nurul Ishlah NW Beleka Kabupaten Lombok Tengah. Jurnal Teknologi Pendidikan: Jurnal Penelitian Dan Pengembangan Pembelajaran, 1(1), 77-87. file:///C:/Users/PC/Downloads/Documents/604-1146-1-SM.pdf.

Fajarwati, S. (2016). Media Pembelajaran Animasi SWISHMAX sebagai Alternatif untuk Siswa SD yang Berkesulitan Belajar pada Materi Bangun Ruang. Probisnis, 9(1), 3851.

Gilboy, M. B., Heinerichs, S., \& Pazzaglia, G. (2015). Enhancing Student Engagement Using The Flipped Classroom. Journal of Nutrition Education and Behavior, 47(1), 109114. https://doi.org/https://doi.org/10.1016/j.jneb.2014.08.008.

Hamalik, O. (2004). Proses Belajar Mengajar. Jakarta: Bumi Aksara.

Hamid, A. (2019). Berbagai Metode Mengajar bagi Guru dalam Proses Pembelajaran. Aktualita: Jurnal Penelitian Sosial Keagamaan, 9(2), 1-16.

Handayani, N. D. (2018). Pengaruh Metode Simulasi terhadap Hasil Belajar Siswa (Studi Kuasi Eksperimen Pada Mata Pelajaran Ekonomi dan Bisnis Kompetensi Dasar Menghitung Biaya Produksi di Kelas X Administrasi Perkantoran SMK Swasta Nasional Bandung Tahun Ajaran 2017/2018). UNPAS.

Handayani, T. (2011). Membangun Komunikasi Efektif Untuk Meningkatkan Kualitas Dalam Proses Belajar Mengajar. Ta'dib, 16(02), 273-302. https://doi.org/https://doi.org/10.19109/tjie.v16i02.64

Hanum, N. S. (2013). Keefetifan E-Learning sebagai Media Pembelajaran (Studi Evaluasi Model Pembelajaran E-Learning SMK Telkom Sandhy Putra Purwokerto). Jurnal Pendidikan Vokasi, 3(1). https://doi.org/https://doi.org/10.21831/jpv.v3i1.1584.

Ikhwan, A. (2017). Metode Simulasi Pembelajaran dalam Perspektif Islam. ISTAWA: Jurnal Pendidikan Islam, 2(2), 1-34. https://doi.org/10.24269/ijpi.v2i2.623.

Kolesnikova, I. V. (2016). Combined Teaching Method: An Experimental Study. World Journal of Education, 6(6), 51-59. https://doi.org/10.5430/wje.v6n6p51.

Lestari, E. C., Hobri, H., \& Kristiana, A. I. (2015). Penerapan Model Pembelajaran Learning Cycle 5E dengan Metode Pemberian Tugas dan Resitasi untuk Meningkatkan Aktivitas dan Hasil Belajar Matematika pada Pokok Bahasan Aritmetika Sosial Siswa Kelas VII A Semester Genap SMP Negeri 10 Jember Tahun Ajaran 2. Kadikma, 6(2). https://jurnal.unej.ac.id/index.php/kadikma/article/view/1987.

Mutia, I., Muhamad, F., \& Rahman, H. (2018). Penerapan Model Pembelajaran Problem Basedlearning terhadap Kemampuan Pemecahan Masalah Matematis Siswa dalam Materi Persamaan Kuadrat Kelas X MA-Ikhlas Beramal Kecamatan Tanah Pinoh Kabupaten Melawi. IKIP PGRI Pontianak. 
Nurdin, M. (2016). Penerapan metode debat aktif untuk meningkatkan kemampuan berdiskusi mahasiswa dalam pembelajaran Konsep Dasar PKn di PGSD UPP Bone FIP UNM. Publikasi Pendidikan: Jurnal Pemikiran, Penelitian Dan Pengabdian Masyarakat Bidang Pendidikan, https://doi.org/https://doi.org/10.26858/publikan.v6i1.1784.

$6(1)$.

Nurhasanah, H. (2017). Peningkatan kemampuan Bina Diri Toilet Training Anak Autis melalui Metode Latihan (Drill) di Pusat Layanan Autis Yogyakarta. Widia Ortodidaktika, 6(2), 149-158. http://journal.student.uny.ac.id/ojs/index.php/plb/article/view/6886.

Nurrohmi, Y., Utaya, S., \& Utomo, D. H. (2017). Pengaruh Model Pembelajaran Discovery Learning Terhadap Kemampuan Berpikir Kritis Mahasiswa. Jurnal Pendidikan: Teori, Penelitian, Dan Pengembangan, 2(10), 1308-1314. https://doi.org/http://dx.doi.org/10.17977/jptpp.v2i10.10062.

Padmowihardjo, S. (2014). Psikologi Belajar Mengajar. Repository.Ut.Ac.Id.

Piona, Y. (2017). Meningkatkan Hasil Belajar Al-Qur'an Hadis dengan Menggunakan Metode Proyek di MI Ismaria Al-Qur'anniyah Rajabasa Bandar Lampung Tahun Pelajaran 2015/2016. UIN Raden Intan Lampung.

Qomariyah, O. N. (2019). Metode Project Based Learning (PJBL) pada Materi Trigonometri. Seminar Nasional Pendidikan, 407-415. http://seminar.umpo.ac.id/index.php/semnasdik2015/article/view/252.

Sartika, S. B. (2012). Pengaruh Penerapan Metode Eksperimen sebagai Implementasi Kurikulum Tingkat Satuan Pendidikan (KTSP) Terhadap Prestasi. Pedagogia: Jurnal Pendidikan, 1(2), 189-212.

Siregar, E. A. (2014). Meningkatkan Keterampilan Bertanya dengan Menggunakan Metode Tanya Jawab Pada Mata Pelajaran PKN Siswa Kelas IV SD. School Education Journal PGSD FIP UNIMED, https://doi.org/https://doi.org/10.24114/sejpgsd.v1i1.1299

Sitompul, D. N. (2015). Pengaruh Penerapan Layanan Bimbingan Kelompok Teknik RolePlaying terhadap Perilaku Solidaritas Siswa dalam Menolong Teman. EduTech: Jurnal Ilmu Pendidikan Dan Ilmu Sosial, 1(01). https://doi.org/10.30596/edutech.v1i01.265.

Sugiyanto, R. (2009). Penerapan Metode Bertanya dalam Kegiatan Praktek Lapangan untuk Meningkatkan Kemampuan Mengemukakan Pendapat Mahasiswa. Jurnal Geografi: Media Informasi Pengembangan Dan Profesi Kegeografian, 6(2), 80-90. https://doi.org/https://doi.org/10.15294/jg.v6i2.94.

Suparya, I. K. (2016). Penerapan Model Problem Base Learning Melalui Lesson Study untuk Meningkatkan Kemampuan Berpikir Kritis pada Mahasiswa Jurusan Pendidikan Guru Pendidikan Anak Usia Dini. JEPUN: Jurnal Pendidikan Universitas Dhyana Pura, $\quad$ 1(1), 69-83. https://jurnal.undhirabali.ac.id/index.php/Jepun/article/view/81.

Suridah, S., Fajar, D., Fahrurrozi, F., Anggraeni, R., Ulfa, R., \& Sonia, S. (2020). Pelaksanaan Metode Karyawisata dalam Pembelajaran Pendidikan Agama Islam di Taman Kanak-Kanak. Al-TA'DIB, 294-305. https://doi.org/10.31332/atdbwv12i2.1341.

Turney, C. (1973). Sidney Micro Skill Hand Book Series 1-5. Sydney University.

Ulfhanny, M. (2018). Pengaruh Penerapan Model Pembelajaran Kooperatif Tipe Jigsaw terhadap Kemampuan Pemecahan Masalah Matematis ditinjau Berdasarkan 
Kemampuan Awal Siswa Sekolah Menengah Pertama di Pekanbaru. Thesis. Universitas Islam Negeri Sultan Syarif Kasim Riau.

Wahidin, U. (2017). Interaksi Komunikasi Berbasis Media Pembelajaran dalam Proses Belajar-Mengajar. Edukasi Islami: Jurnal Pendidikan Islam, 4(07), 197. https://doi.org/10.30868/ei.v4i07.63.

Wati, N. N. K. (2020). Implementasi Metode Demonstrasi Berbantuan Google Classroom Untuk Meningkatkan Minat Belajar Mahasiswa Kelas A Prodi PGSD. EdukasI: Jurnal Pendidikan Dasar, 1(1), 29-37. file:///C:/Users/PC/Downloads/525-961-1SM.pdf.

Winataputra, U. S., Delfi, R., Pannen, P., \& Mustafa, D. (2014). Teori Belajar dan Pembelajaran. Repository.Ut.Ac.Id.

Wiranty, W., \& Mastuti, D. L. (2018). Upaya Peningkatan Keaktifan Mahasiswa dalam Pembelajaran melalui Metode Presentasi Kelas Tahun Akademik 2016/2017 Semester Genap. Jurnal Pendidikan Bahasa, 7(1), 129-142. https://doi.org/http://dx.doi.org/10.31571/bahasa.v7i1.832.

Yulianti, H., Iwan, C. D., \& Millah, S. (2018). Penerapan Metode Giving Question and Getting Answer untuk Meningkatkan Hasil Belajar Peserta Didik pada Mata Pelajaran Pendidikan Agama Islam. Jurnal Penelitian Pendidikan Islam, 6(2), 197. https://doi.org/10.36667/jppi.v6i2.297. 